\title{
Biplot analysis of strawberry genotypes recommended for the State of Espírito Santo
}

\author{
A.F. Costa ${ }^{1}$, P.E. Teodoro ${ }^{2}$, L.L. Bhering ${ }^{2}$, N.R. Leal ${ }^{3}$, F.D. Tardin ${ }^{4}$ and \\ R.F. Daher ${ }^{3}$ \\ ${ }^{1}$ Instituto Capixaba de Pesquisa, Assistência Técnica e Extensão Rural, \\ Centro Regional de Desenvolvimento Rural, Centro Serrano, \\ Domingos Martins, ES, Brasil \\ ${ }^{2}$ Laboratório de Biometria, Departamento de Biologia Geral, \\ Universidade Federal de Viçosa, Viçosa, MG, Brasil \\ ${ }^{3}$ Laboratório de Melhoramento Genético Vegetal, \\ Universidade Estadual do Norte Fluminense "Darcy Ribeiro", \\ Campos dos Goytacazes, RJ, Brasil \\ ${ }^{4}$ Núcleo de Desenvolvimento de Cultivares, Embrapa Milho e Sorgo, Sinop, \\ MT, Brasil \\ Corresponding author: P.E. Teodoro \\ E-mail: eduteodoro@hotmail.com
}

Genet. Mol. Res. 15 (3): gmr.15038919

Received June 24, 2016

Accepted August 8, 2016

Published August 26, 2016

DOI http://dx.doi.org/10.4238/gmr.15038919

Copyright (C) 2016 The Authors. This is an open-access article distributed under the terms of the Creative Commons Attribution ShareAlike (CC BY-SA) 4.0 License.

ABSTRACT. Most strawberry genotypes grown commercially in Brazil originate from breeding programs in the United States, and are therefore not adapted to the various soil and climatic conditions found in Brazil. Thus, quantifying the magnitude of genotype $\mathrm{x}$ environment (GE) interactions serves as a primary means for increasing average Brazilian strawberry yields, and helps provide specific recommendations for farmers on which genotypes meet high yield and phenotypic stability thresholds. The aim of this study was to use AMMI (additive main effects 
and multiplicative interaction) and GGE biplot (genotype main effects + genotype x environment interaction) analyses to identify high-yield, stable strawberry genotypes grown at three locations in Espírito Santo for two agricultural years. We evaluated seven strawberry genotypes (Dover, Camino Real, Ventana, Camarosa, Seascape, Diamante, and Aromas) at three locations (Domingos Martins, Iúna, and Muniz Freire) in agricultural years 2006 and 2007, totaling six study environments. Joint analysis of variance was calculated using yield data ( $\mathrm{t} / \mathrm{ha})$, and AMMI and GGE biplot analysis was conducted following the detection of a significant genotypes $\mathrm{x}$ agricultural years $\mathrm{x}$ locations $(\mathrm{G} \times \mathrm{A} \times \mathrm{L})$ interaction. During the two agricultural years, evaluated locations were allocated to different regions on biplot graphics using both methods, indicating distinctions among them. Based on the results obtained from the two methods used in this study to investigate the $\mathrm{G} \times \mathrm{A} \times$ $\mathrm{L}$ interaction, we recommend growing the Camarosa genotype for production at the three locations assessed due to the high frequency of favorable alleles, which were expressed in all localities evaluated regardless of the agricultural year.

Key words: Fragaria $x$ ananassa; Genotype x environment interaction; Yield

\section{INTRODUCTION}

Strawberry plants (Fragaria x ananassa Duch.) belong to the family Rosaceae, and are a crop of economic importance that is highly appreciated worldwide for its organoleptic characteristics and health benefits (Lopes et al., 2015). Strawberries are grown in temperate and subtropical climate regions in Brazil, and are mainly produced on small farms for either in natura consumption or subsequent processing (Witter et al., 2012). According to Randin et al. (2011), Brazil's annual strawberry production is around 100,000 tons, with an average yield of 30 tons per hectare. In Espírito Santo State, strawberry cultivation has increased over the years, and has played an important socioeconomic role, mainly due to the increased income associated with small farms and the establishment of more workers in rural areas as a result of the amount of manual labor required during the growing season (Costa et al., 2015).

Most strawberry genotypes grown commercially in Brazil originate from breeding programs in the United States (Antunes and Reisser Júnior, 2007), and are therefore not adapted to the various soil and climatic conditions found in Brazil. The expression of productivity potential depends not only on genetic and environmental factors, but also on interactions between the two, resulting in significant differences in genotype performance under disparate environmental growing conditions. In biometrical models, the term "environment" (in relation to agricultural year, sowing time, local and cultural practices, etc.) can be defined as the result of biophysical components that influence the development and growth of plants (Silva et al., 2011b).

Quantifying the magnitude of genotype $\mathrm{x}$ environment (GE) interactions facilitates the identification of stable genotypes and helps provide production recommendations, which are especially useful given the wide adaptability of strawberries to many different locations. Genotypes adapted to harsh environments, for example, may be more suitable for small

Genetics and Molecular Research 15 (3): gmr.15038919 
producers using low-tech farming methods, whereas genotypes responsive to environmental improvements may flourish under higher technological practices. Thus, the study of GE interactions represents one of the primary ways for increasing average yields of Brazilian strawberries, as well as for providing specific recommendations to farmers on which genotypes meet high yield and phenotypic stability thresholds.

Various methods of analyzing GE interactions have been developed over the last several decades, but the use of multivariate analysis techniques associated with biplot graphics has greatly enhanced the ability to provide genotypic recommendations to producers and breeders. AMMI (additive main effects and multiplicative interaction) and GGE biplot (genotype main effects + genotype x environment interaction) analyses are currently among the most used adaptability and stability methods undertaken for investigating GE interactions (Farias et al., 2016; Teodoro et al., 2016). Both forms of analysis utilize biplot graphs, which represent a given data matrix. GGE models directly analyze the effect of genotype (G) + GE (Yan et al., 2000), whereas AMMI models separate $\mathrm{G}$ from GE; the final stage of analysis produces biplot graphs based on data collected through these two methodologies (Gauch and Zobel, 1988).

These methods have been used in Brazil for providing production recommendations related to cotton (Farias et al., 2016), cowpea (Santos et al., 2015), carrot (Silva et al., 2011a), maize (Balestre et al., 2009a,b), and wheat (Silva et al., 2011b; Benin et al., 2012) genotypes. Thus, the aim of this study was to use both AMMI and GGE biplot analyses to identify strawberry genotypes demonstrating high yield and stability thresholds among those grown at three locations in Espírito Santo during two agricultural years.

\section{MATERIAL AND METHODS}

We evaluated seven strawberry genotypes (Dover, Camino Real, Ventana, Camarosa, Seascape, Diamante, and Aromas) at three locations in Espírito Santo during two agricultural years (2006/2007 and 2007/2008), totaling six study environments (Table 1). In each experiment, we used a randomized block design consisting of 3 replications and 15 plants per plot. Each experimental unit was composed of three lines spaced at a distance of $0.40 \times 0.40$ $\mathrm{m}$ between plants, in $0.30 \mathrm{~m}$ high beds covered with black mulch. In all environments, plants were covered with a white plastic film, which was suspended on galvanized iron arches $1.0 \mathrm{~m}$ high. In all environments, planting began in late May, with harvests performed twice a week from the beginning of the harvest (usually in August) until the end of the cycle.

Table 1. Abbreviation, composition, and geographical features of the six environments evaluated.

\begin{tabular}{l|c|l|c|c|c}
\hline Abbreviation & Agricultural year & Location & Altitude $(\mathrm{m})$ & Latitude $\left({ }^{\circ} \mathrm{S}\right)$ & Longitude $\left({ }^{\circ} \mathrm{W}\right)$ \\
\hline E1 & $2006 / 2007$ & Domingos Martins & 950 & 20.372 & 41.064 \\
\hline E2 & $2006 / 2007$ & Iúna & 758 & 20.357 & 41.557 \\
\hline E3 & $2006 / 2007$ & Muniz Freire & 575 & 20.470 & 41.420 \\
\hline E4 & $2007 / 2008$ & Domingos Martins & 950 & 20.372 & 41.064 \\
\hline E5 & $2007 / 2008$ & Iúna & 758 & 20.357 & 41.557 \\
\hline E6 & $2007 / 2008$ & Muniz Freire & 575 & 20.470 & 41.420 \\
\hline
\end{tabular}

Analysis of variance of fruit yield data ( $t /$ ha) was calculated according to the statistical model expressed in equation 1:

Genetics and Molecular Research 15 (3): gmr.15038919 
$\mathrm{Y}_{\mathrm{ijkm}}=\mu+\mathrm{G}_{\mathrm{i}}+\mathrm{A}_{\mathrm{j}}+\mathrm{L}_{\mathrm{k}}+(\mathrm{B} / \mathrm{Y}) / \mathrm{L}_{\mathrm{j} k \mathrm{~m}}+\mathrm{GY}_{\mathrm{ij}}+\mathrm{GL}_{\mathrm{ik}}+\mathrm{AL}_{\mathrm{jk}}+\mathrm{GAL}_{\mathrm{ijk}}+\varepsilon_{\mathrm{ijkm}}$

Equation 1

where: $\mathrm{Y}_{\mathrm{i} \mathrm{km}}$ is the value observed in the $\mathrm{m}$-th block, evaluated in the $\mathrm{i}$-th genotype, $\mathrm{j}$-th year, and k-th location; $\mu$ is the overall mean; $G_{i}$ is the effect of genotypes assumed as fixed; $A_{j}$ is the effect of agricultural years assumed as fixed; $L_{k}$ is the effect of locations assumed as fixed; $(\mathrm{B} / \mathrm{Y}) / \mathrm{L}_{\mathrm{jkm}}$ is the effect of blocks within years within locations; $\mathrm{GA}_{\mathrm{ij}}$ is the effect of the interaction between genotypes and agricultural years; $\mathrm{GL}_{\mathrm{ik}}$ is the effect of the interaction between genotype and locations; $\mathrm{YL}_{\mathrm{jk}}$ is the effect of the interaction between years and locations; $\mathrm{GAL}_{\mathrm{ijk}}$ is the effect of the triple interaction between genotype, agricultural years, and locations; $\varepsilon_{\mathrm{ijkm}}$ is the random error.

Following the detection of a significant triple interaction [genotypes $\mathrm{x}$ agricultural years $\mathrm{x}$ locations ( $\mathrm{G} \times \mathrm{A} \times \mathrm{L})$ ], we conducted cluster analysis of genotypes and locations means groups for each year using the Scott-Knott test, modified by Bhering et al. (2008). Thus, the genotypes and locations used in each agricultural year have subsequently undergone adaptability and stability analysis using both AMMI (Gauch and Zobel, 1988) and GGE biplot (Yan et al., 2000) methods. Using AMMI-biplot analyses for each year, we adopted the following statistical model (Equation 2):

$$
\mathrm{Y}_{\mathrm{ik}}=\mu+\mathrm{G}_{\mathrm{i}}+\mathrm{L}_{\mathrm{k}}+\sum_{\mathrm{p}=1}^{\mathrm{n}} \lambda_{\mathrm{p}} \gamma_{\mathrm{ip}} \alpha_{\mathrm{kp}}+\rho_{\mathrm{ik}}+\bar{\varepsilon}_{\mathrm{ik}}
$$

Equation 2

where: $Y_{i k}$ is the observed value of genotype $i$ at environment $k$; $\mu$ is the overall mean; $G_{i}$ is the effect of genotypes assumed as fixed; $L_{k}$ is the effect of locations assumed as fixed; $\lambda_{p}$ is the p-th singular value (scalar) from the interaction matrix (denoted by G x L); $\gamma_{\mathrm{ip}}$ is the element corresponding to $\mathrm{i}$-th genotype on the $\mathrm{p}$-th singular vector column of the matrix Gx L; $\alpha_{\mathrm{kp}}$ is the element corresponding to k-th environment on $\mathrm{p}$-th singular vector line of the matrix GL; $\rho_{\mathrm{ik}}$ is the noise associated with the term $(\mathrm{gxl})_{\mathrm{ij}}$ from the interaction between the genotype $\mathrm{i}$ with environment k; $\bar{\varepsilon}_{\mathrm{ik}}$ is the average experimental error.

GGE biplot models do not separate $\mathrm{G}$ from $\mathrm{G} \times \mathrm{E}$, but rather keep them together as two multiplicative terms, as seen in Equation 3:

$$
\mathrm{Y}_{\mathrm{ik}}-\mathrm{y}_{\mathrm{k}}=\mathrm{y}_{1} \varepsilon_{\mathrm{i} 1} \rho_{\mathrm{k} 1}+\mathrm{y}_{2} \varepsilon_{\mathrm{i} 2} \rho_{\mathrm{k} 2}+\bar{\varepsilon}_{\mathrm{ik}} \quad \text { Equation } 3
$$

where: $Y_{i k}$ is the observed value of the genotype $i$ at environment $k ; y_{k}$ is the overall mean of the genotypes at environment $\mathrm{k} ; \mathrm{y}_{1} \varepsilon_{\mathrm{i} 1} \rho_{\mathrm{k} 1}$ is the first principal component (PC1); $\mathrm{y}_{2} \varepsilon_{\mathrm{i} 2} \rho_{\mathrm{k} 2}$ is the second principal component (PC2); $\mathrm{y}_{1}$ and $\mathrm{y}_{2}$ are the eigenvalues associated with IPCA1 and IPCA2, respectively; $\varepsilon_{1}$ and $\varepsilon_{2}$ are the values of PC1 and PC2, respectively, of the genotype $\mathrm{i} ; \rho_{\mathrm{j} 1}$ and $\rho_{\mathrm{j} 2}$ are the values of PC1 and PC2, respectively, for the environment k; $\bar{\varepsilon}_{\mathrm{ik}}$ is the average experimental error. The analyses were performed with the assistance of the Genes software (Cruz, 2013) and Agricolae and GGEGui packages deployed using the R software (R Development Core Team, 2015).

\section{RESULTS AND DISCUSSION}

Joint ANOVA revealed that the effect of $\mathrm{G} \times \mathrm{A} \times \mathrm{L}$, and their interactions were

Genetics and Molecular Research 15 (3): gmr.15038919 
significant $(\mathrm{P}<0.01)$ (Table 2$)$. These results indicate that the performance of genotypes changes depending on the agricultural year (time interaction) and locale (regional interaction), making it more difficult to provide production recommendations (Costa et al., 2015). According to Cruz et al. (2012), a coefficient of experimental variation estimates (CV) below $20 \%$ denotes a high level of experimental precision for phenotypic traits with continuous distribution. The value obtained from this study $(\mathrm{CV}=19.26 \%)$ thus indicates reliable results, and corresponds with observed results for this trait as noted in other strawberry crop studies (Radmann et al., 2006; Moncada et al., 2008; Resende et al., 2010; Randin et al., 2011; Costa et al., 2015).

Table 2. Summary of joint analysis of variance for yield of seven strawberry genotypes evaluated at three locations in the State of Espírito Santo during two agricultural years.

\begin{tabular}{l|c|c}
\hline Sources of variation & Degrees of freedom & Mean square \\
\hline Genotypes (G) & 6 & $531.87^{*}$ \\
\hline Agricultural years (A) & 1 & $2114.21^{*}$ \\
\hline Locations (L) & 2 & $2437.03^{*}$ \\
\hline G x A & 6 & $206.51^{*}$ \\
\hline G L & 12 & $82.55^{*}$ \\
\hline Y x L & 2 & $799.41^{*}$ \\
\hline G x A L & 12 & $81.59^{*}$ \\
\hline Residue & 72 & 15.20 \\
\hline Overall mean (t/ha) & 20.24 & \\
\hline Coefficient of variation (\%) & 19.26 & \\
\hline
\end{tabular}

*Significant at $1 \%$ probability by the $\mathrm{F}$ test.

In the agricultural year 2006/2007, the genotype Camino Real presented the highest production average among all evaluated environments (Table 3), whereas the genotype Camarosa exhibited the highest production average in the agricultural year 2007/2008. It is important to note that the Camarosa genotype also comprised the group having the highest averages at both Iúna and Muniz Freire locations in 2006/2007, whereas Camino Real was among the most productive genotypes in Muniz Freire in the same agricultural year. Although we verified that the Domingos Martins location had the highest production average for production in 2006/2007 as compared with the others, these results were not repeated in the agricultural year 2007/2008 for two of the genotypes (Dover and Ventana). The Iúna location site was found to be superior to the others in the agricultural year 2007/2008 for all genotypes, but in the previous harvest, this only happened for three of the genotypes (Camarosa, Seascape, and Diamante). Changes in the ordering of genotypes depending on variations in location in both years indicate that the G x L interaction is inherently complex, and is a characteristic that can be attributed to unpredictable factors such as rainfall amounts, temperature fluctuations, humidity levels, and the occurrence of pests and diseases (Cruz et al., 2012). Thus, it is necessary to use adaptability and stability analysis to help provide more reliable recommendations related to the selection of production genotypes.

On the AMMI1 biplot graph (Figure 1), stability is indicated by the ordinate axis, with stable genotypes and environments having score values closest to zero; adaptability is shown on the x-axis, and is plotted using mean calculations for the surveyed genotypes and environments (Gauch and Zobel, 1988). The genotypes Ventana and Seascape produced the greatest magnitude of scores (in absolute values) on the interaction axis, and were shown to be highly unstable in the agricultural year 2006/2007, whereas the Camino Real and Aromas genotypes were shown to be the most unstable genotypes surveyed in the 2007/2008

Genetics and Molecular Research 15 (3): gmr.15038919 
agricultural year. In the 2006/2007 agricultural year (Figure 1A), both Camarosa and Camino Real genotypes indicated high productivity and phenotypic stability levels, but for this specific period, only the Camarosa genotype can be considered stable and productive.

Table 3. Mean values for yield of seven strawberry genotypes evaluated at three locations in the State of Espírito Santo during two years.

\begin{tabular}{|c|c|c|c|}
\hline Genotype & Domingos Martins & Iúna & Muniz Freire \\
\hline \multicolumn{4}{|l|}{$2006 / 2007$} \\
\hline Dover & $15.34^{\mathrm{Ac}}$ & $7.77^{\mathrm{Bb}}$ & $4.86^{\mathrm{Bb}}$ \\
\hline Camino Real & $31.34^{\mathrm{Aa}}$ & $21.26^{\mathrm{Ba}}$ & $19.57^{\mathrm{Ba}}$ \\
\hline Ventana & $23.51^{\mathrm{Ab}}$ & $10.40^{\mathrm{Bb}}$ & $4.44^{\mathrm{Bb}}$ \\
\hline Camarosa & $24.21^{\mathrm{Ab}}$ & $19.08^{\mathrm{Aa}}$ & $12.13^{\mathrm{Ba}}$ \\
\hline Seascape & $13.92^{\mathrm{Ac}}$ & $12.93^{\mathrm{Ab}}$ & $14.84^{\mathrm{Aa}}$ \\
\hline Diamante & $22.36^{\mathrm{Ab}}$ & $17.40^{\mathrm{Aa}}$ & $9.43^{\mathrm{Bb}}$ \\
\hline Aromas & $22.83^{\mathrm{Ab}}$ & $17.33^{\mathrm{Ba}}$ & $14.01^{\mathrm{Ba}}$ \\
\hline \multicolumn{4}{|l|}{$2007 / 2008$} \\
\hline Dover & $14.50^{\mathrm{Bd}}$ & $22.25^{\mathrm{Ad}}$ & $5.37^{\mathrm{Cb}}$ \\
\hline Camino Real & $25.99^{\mathrm{Ac}}$ & $22.42^{\mathrm{Ad}}$ & $15.62^{\mathrm{Ba}}$ \\
\hline Ventana & $15.32^{\mathrm{Bd}}$ & $27.15^{\mathrm{Ad}}$ & $9.58^{\mathrm{Cb}}$ \\
\hline Camarosa & $40.33^{\mathrm{Aa}}$ & $53.28^{\mathrm{Aa}}$ & $18.06^{\mathrm{Ba}}$ \\
\hline Seascape & $31.27^{\mathrm{Ab}}$ & $27.07^{\mathrm{Ad}}$ & $16.57^{\mathrm{Ba}}$ \\
\hline Diamante & $34.57^{\mathrm{Ab}}$ & $35.09^{\mathrm{Ac}}$ & $8.87^{\mathrm{Bb}}$ \\
\hline Aromas & $38.54^{\mathrm{Aa}}$ & $41.83^{\mathrm{Ab}}$ & $7.30^{\mathrm{Bb}}$ \\
\hline
\end{tabular}

For each crop year, means groups followed by different capital letters in the same line, and lowercase letters in the same column, differ by $5 \%$ probability by the Scott-Knott test, modified by Bhering et al. (2008).

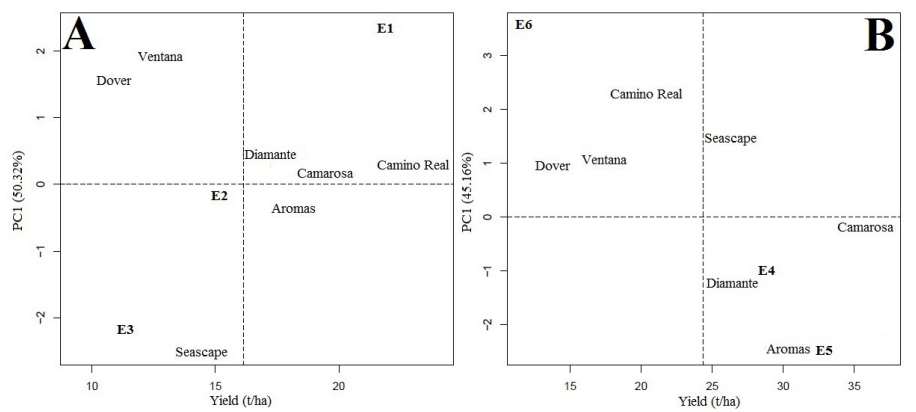

Figure 1. Biplot AMMI for principal effects, with $\mathrm{G} \times \mathrm{L}$ interaction for yield, of seven strawberry genotypes evaluated at three locations in 2006/2007 (A) and 2007/2008 (B).

In the agricultural year 2006/2007, data indicate that the site at Iúna (E2) could be considered the most stable location among those surveyed, but additional findings related to the next crop cultivated at this location (E5) show that it was, in fact, among the most unstable sites, along with that at Muniz Freire (E6). According to Oliveira et al. (2003), environmental stability is a very important factor to consider because it provides information about the reliability in ordering genotypes within a given test environment in relation to the mean rating for all tested environments. Figure 1B indicates further need to check specific interactions between genotype Diamante with location Muniz Freire (E4) and genotype Aromas with location Iúna (E5), although these associations do only occur in the agricultural year 2007/2008, which indicates an inherent level of unpredictability in the performance of these genotypes over this time period.

Genetics and Molecular Research 15 (3): gmr.15038919 
Figure 2A (2006/2007) shows a polygon connecting genotypes Ventana, Camino Real, Seascape, and Diamante, all of which are located farthest from the biplot origin. In the agricultural year 2007/2008 (Figure 2B), only the Camarosa genotype was located within the polygon. Genotypes, which constitute each vertex of the polygons, it has the largest vectors in the respective directions; the length and direction of vector represents the extent of the tested genotypes response are less sensitive in relation to the interaction with the environments of each sector (Yan and Rajcan, 2002).
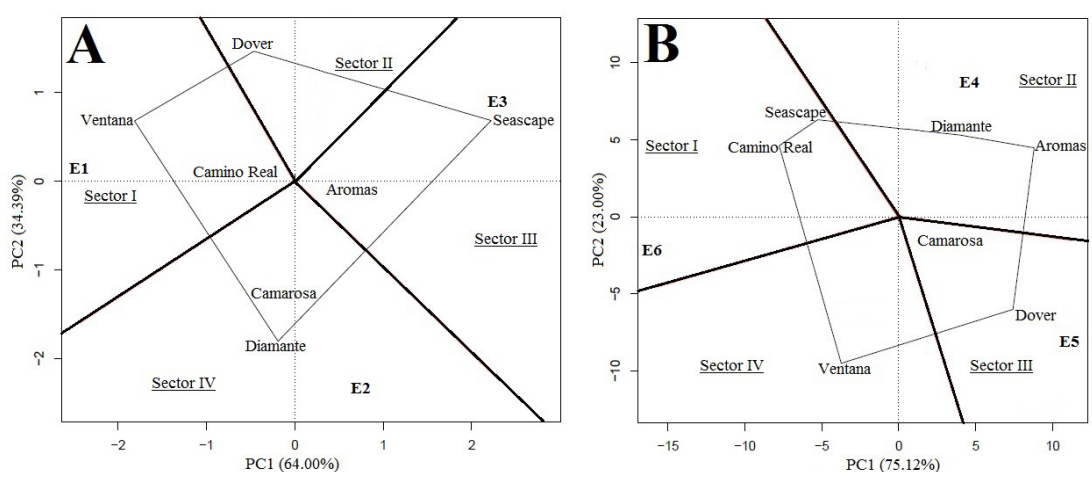

Figure 2. Sectors obtained from the GGE biplot model for yield of seven strawberry genotypes evaluated at three locations in 2006/2007 (A) and 2007/2008 (B).

Vectors extending from the center biplot $(0,0)$, perpendicular to the sides of the polygon, divide the graphs into four sectors for both years, with each environment grouped within a sector. Results indicate that the environmental contrast for each site does not occur in relation to interaction time. When genotypes give rise to vertices of the polygon, but the polygon itself does not contain any clustered environments, these genotypes are thus considered unfavorable among the tested environments groups, indicating low productivity (Karimizadeh et al., 2013). Thus, the Dover genotype contained within sector II of Figure 2A, and the Ventana genotype contained within sector IV of Figure $2 \mathrm{~B}$ are considered unfavorable with regard to productivity recommendations associated with these locations. These results are confirmed by the data shown in Figure 1, which indicates that these genotypes demonstrated low yield and instability among the surveyed environments in both agricultural years.

An ideal strawberry genotype should have an average yield that is consistently high in all evaluated environments. This ideal genotype is graphically defined by the longest vector in $\mathrm{PC} 1$ and PC2 without projections, and is represented by the arrow in the center of concentric circles (Yan and Rajcan, 2002). Although this genotype is merely a representative model, it can be used as a rating reference for the Camarosa genotype, which was located in the first and second concentric circles in agricultural years 2006/2007 and 2007/2008 (Figure 3), respectively. Thus, Camarosa is indicated as the closest surveyed genotype to the ideal model for production within the evaluated environments. These results correspond to those reported by Resende et al. (2010) and Randin et al. (2011), which verified that this genotype results in high productivity yields in three cultivation environments evaluated in the State of Paraná and in two locations surveyed in Rio Grande do Sul, respectively.

Genetics and Molecular Research 15 (3): gmr.15038919 

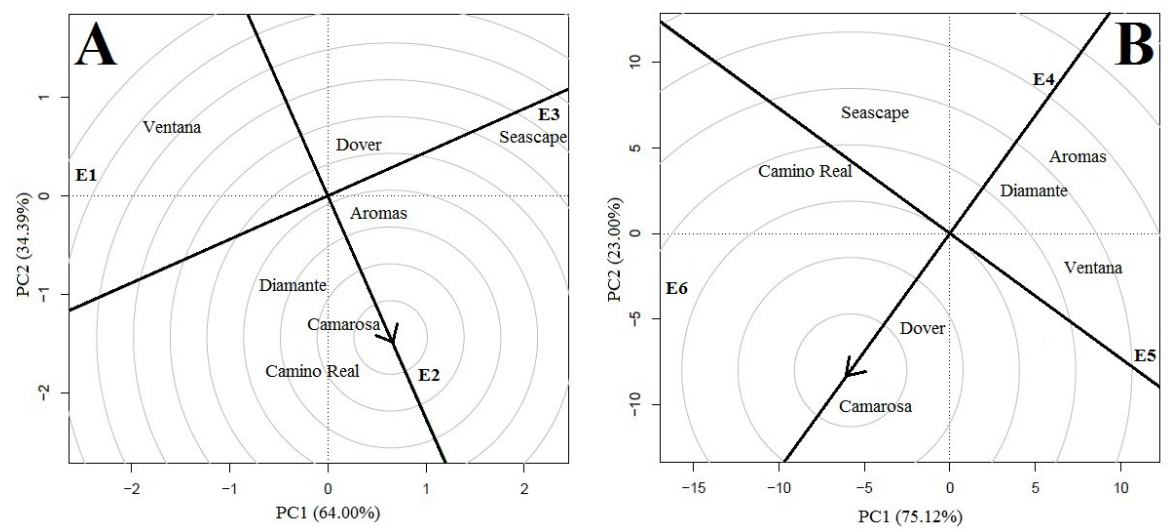

Figure 3. Classification of genotypes according to the GGE biplot model for yield of seven strawberry genotypes evaluated at three locations in 2006/2007 (A) and 2007/2008 (B).

In sum, based on the results obtained from the two methods used in this study to investigate the $\mathrm{G} \times \mathrm{A} \times \mathrm{L}$ interaction, we recommend growing the Camarosa genotype for production at the three locations assessed due to the high frequency of favorable alleles, which were expressed in all localities evaluated regardless of agricultural year. We further recommend that future studies evaluate this genotype using different growing strategies (e.g., open air, high tunnel, and low tunnel) in relation to other locations within the experimental network.

\section{Conflicts of interest}

The authors declare no conflict of interest.

\section{ACKNOWLEDGMENTS}

We would like to thank Fundação de Amparo à Pesquisa e Inovação do Espírito Santo (FAPES) for providing financial support for this research.

\section{REFERENCES}

Antunes LEC and Reisser Júnior C (2007). Fragole, i prodottori brasiliani mirano all'esportazione in Europa. Frutticoltura 69: 60-65.

Balestre M, Von Pinho RG, Souza JC and Oliveira RL (2009a). Genotypic stability and adaptability in tropical maize based on AMMI and GGE biplot analysis. Genet. Mol. Res. 8: 1311-1322 http://dx.doi.org/10.4238/vol8-4gmr658.

Balestre M, Souza JC, Pinho RGV, Oliveira RL, et al. (2009b). Yield stability and adaptability of maize hybrids based on GGE biplot analysis characteristics. Crop Breed. Appl. Biotechnol. 9: 219-228. http://dx.doi.org/10.12702/19847033.v09n03a03

Benin G, Pinnow C, Silva CL, Pagliosa ES, et al. (2012). Análises biplot na avaliação de cultivares de trigo em diferentes níveis de manejo. Bragantia 71: 28-36 10.1590/S0006-87052012000100005.

Bhering LL, Cruz CD, De Vasconcelos ES, Ferreira A, et al. (2008). Alternative methodology for Scott-Knott test. Crop Breed. Appl. Biotechnol. 8: 9-16 http://dx.doi.org/10.12702/1984-7033.v08n01a02.

Costa AF, Leal NR, Ventura JA, Gonçalves LSA, et al. (2015). Adaptability and stability of strawberry cultivars using a mixed model. Acta Sci. Agron. 37: 435-440 http://dx.doi.org/10.4025/actasciagron.v37i4.18251.

Cruz CD (2013). Genes: a software package for analysis in experimental statistics and quantitative genetics. Acta Sci. Agron. 35: 271-276 http://dx.doi.org/10.4025/actasciagron.v35i3.21251.

Genetics and Molecular Research 15 (3): gmr.15038919 
Cruz CD, Carneiro PCS and Regazzi AJ (2012). Modelos biométricos aplicados ao melhoramento genético. 3rd edn. Editora UFV, Viçosa.

Farias FJC, Carvalho LP, Silva Filho JL and Teodoro PE (2016). Biplot analysis of phenotypic stability in upland cotton genotypes in Mato Grosso. Genet. Mol. Res. 15: gmr.15028009. http://dx.doi.org/10.4238/gmr.15028009

Gauch HG, Jr. and Zobel RW (1988). Predictive and postdictive success of statistical analyses of yield trials. Theor. Appl. Genet. 76: 1-10 http://dx.doi.org/10.1007/BF00288824.

Karimizadeh R, Mohammadi M, Sabaghni N, Mahmoodi SA, et al. (2013). GGE Biplot Analysis of Yield Stability in Multi-environment Trials of Lentil Genotypes under Rainfed Condition. Not. Sci. Biol. 5: 256-262.

Lopes PZ, Fornazzari IM, Almeida AT, Galvão CW, et al. (2015). Effect of ethylene treatment on phytochemical and ethylene-related gene expression during ripening in strawberry fruit Fragaria x ananassa cv. Camino Real. Genet. Mol. Res. 14: 16113-16125 http://dx.doi.org/10.4238/2015.December.7.23.

Moncada A, Miceli A and D'Anna F (2008). Evaluation of strawberry cultivars in soilless cultivation in Sicily. Acta Hortic. 801: 1121-1128 http://dx.doi.org/10.17660/ActaHortic.2008.801.135.

Oliveira AB, Duarte JB and Pinheiro JB (2003). Emprego da análise AMMI na avaliação da estabilidade produtiva em soja. Pesq. Agropec. Bras. 38: 357-364 http://dx.doi.org/10.1590/S0100-204X2003000300004.

R Development Core Team (2015). R: a language and environment for statistical computing. Vienna: R Foundation for Statistical Computing. http://www.R-project.org. Accessed April 15, 2015.

Randin B, Lisboa BB, Witter S, Barni V, et al. (2011). Desempenho de quatro cultivares de morangueiro em duas regiões ecoclimáticas do Rio Grande do Sul. Hortic. Bras. 29: 287-291. http://dx.doi.org/10.1590/S0102-05362011000300005

Radmann EB, Bianchi VJ, Oliveira RP and Fachinello JC (2006). Caracterização e diversidade genética de cultivares de morangueiro. Hortic. Bras. 24: 84-87. http://dx.doi.org/10.1590/S0102-05362006000100017

Resende JTV, Morales RGF, Faria MV, Rissini ALL, et al. (2010). Produtividade e teor de sólidos solúveis de frutos de cultivares de morangueiro em ambiente protegido. Hortic. Bras. 28: 185-189. http://dx.doi.org/10.1590/S0102$\underline{05362010000200008}$

Santos A, Ceccon G, Rodrigues EV, Teodoro PE, et al. (2015). Adaptability and stability of cowpea genotypes to Brazilian Midwest. Afr. J. Agric. Res. 10: 3901-3908 http://dx.doi.org/10.5897/AJAR2015.10165.

Silva GO, Carvalho ADF, Vieira JV and Benin G (2011a). Verificação da adaptabilidade e estabilidade de populações de cenoura pelos métodos AMMI, GGE biplot e REML/BLUP. Bragantia 70: 494-501 http://dx.doi.org/10.1590/ $\underline{\text { S0006-87052011005000003. }}$.

Silva RR, Benin G, Silva GO, Marchioro VS, et al. (2011b). Adaptabilidade e estabilidade de cultivares de trigo em diferentes épocas de semeadura, no Paraná. Pesq. Agropec. Bras. 46: 1439-1447 http://dx.doi.org/10.1590/S0100204X2011001100004.

Teodoro PE, Almeida Filho JE, Daher RF, Menezes CB, et al. (2016). Identification of sorghum hybrids with high phenotypic stability using GGE biplot methodology. Genet. Mol. Res. 15: gmr.15027914. http://dx.doi.org/10.4238/ gmr.15027914

Witter S, Radin B, Lisboa BB, Teixeira JSG, et al. (2012). Desempenho de cultivares de morango submetidas a diferentes tipos de polinização em cultivo protegido. Pesq. Agropec. Bras. 47: 58-65. http://dx.doi.org/10.1590/S0100$\underline{204 X 2012000100009}$

Yan W and Rajcan I (2002). Biplot Analysis of Test Sites and Trait Relations of Soybean in Ontario. Crop Sci. 42: 11-20 http://dx.doi.org/10.2135/cropsci2002.0011.

Yan W, Hunt LA, Sheng Q and Szlavnics Z (2000). Cultivar Evaluation and Mega-Environment Investigation Based on the GGE Biplot. Crop Sci. 40: 597-605 http://dx.doi.org/10.2135/cropsci2000.403597x.

Genetics and Molecular Research 15 (3): gmr.15038919 